\title{
The Old Testament or Hebrew Bible in Africa: Challenges and prospects for interpretation and translation
}

\begin{tabular}{|c|c|}
\hline \multicolumn{2}{|c|}{$\begin{array}{l}\text { Author: } \\
\text { Aloo O. Mojola }{ }^{1,2}\end{array}$} \\
\hline \multicolumn{2}{|c|}{$\begin{array}{l}\text { Affiliations: } \\
{ }^{1} \text { Department of Old } \\
\text { Testament Studies, } \\
\text { University of Pretoria, } \\
\text { South Africa }\end{array}$} \\
\hline \multicolumn{2}{|c|}{${ }^{2}$ United Bible Societies, Africa } \\
\hline \multicolumn{2}{|c|}{$\begin{array}{l}\text { Correspondence to: } \\
\text { Aloo Mojola }\end{array}$} \\
\hline \multicolumn{2}{|c|}{$\begin{array}{l}\text { Email: } \\
\text { aloo.mojola@gmail.com }\end{array}$} \\
\hline \multicolumn{2}{|c|}{$\begin{array}{l}\text { Postal address: } \\
\text { PO Box 55779, Nairobi } \\
\text { 00200, Kenya }\end{array}$} \\
\hline \multicolumn{2}{|c|}{$\begin{array}{l}\text { Dates: } \\
\text { Received: } 03 \text { Oct. } 2013 \\
\text { Accepted: } 30 \text { May } 2014 \\
\text { Published: } 04 \text { Sept. } 2014\end{array}$} \\
\hline \multicolumn{2}{|c|}{$\begin{array}{l}\text { How to cite this article: } \\
\text { Mojola, A.O., 2014, 'The Old } \\
\text { Testament or Hebrew Bible } \\
\text { in Africa: Challenges and } \\
\text { prospects for interpretation } \\
\text { and translation', Verbum et } \\
\text { Ecclesia } 35(3), \text { Art. \#1307, } \\
7 \text { pages. http://dx.doi. } \\
\text { org/10.4102/ve.v35i3.1307 }\end{array}$} \\
\hline \multicolumn{2}{|c|}{$\begin{array}{l}\text { Note: } \\
\text { Prof. Dr Aloo O. Mojola } \\
\text { is a Research Associate } \\
\text { for the Department of } \\
\text { Old Testament Studies at } \\
\text { University of Pretoria, } \\
\text { South Africa. }\end{array}$} \\
\hline \multicolumn{2}{|c|}{$\begin{array}{l}\text { Copyright: } \\
\text { (C) 2014. The Authors. } \\
\text { Licensee: AOSIS } \\
\text { OpenJournals. This wor } \\
\text { is licensed under the } \\
\text { Creative Commons } \\
\text { Attribution License. }\end{array}$} \\
\hline \multicolumn{2}{|l|}{ Read online: } \\
\hline 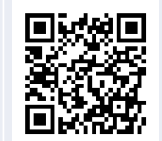 & $\begin{array}{l}\text { Scan this QR } \\
\text { code with your } \\
\text { smart phone or } \\
\text { mobile device } \\
\text { to read online. }\end{array}$ \\
\hline
\end{tabular}

The Old Testament or Hebrew Bible is much loved in Africa. It is however encountered almost exclusively in translation, either through translation into local indigenous languages or translation into foreign, non-local languages. The source language Hebrew text is inaccessible to the vast majority of readers, including Christian pastors or theological students who would naturally be expected to have access by virtue of their profession. Knowledge of the Old Testament or Hebrew Bible is thus mediated through existing translations and interpretations, and through the popular or scholarly writings of Old Testament or Hebrew Bible experts. In many parts of Africa the latter are in very short supply. This article is an attempt to engage and critically reflect further on some of the issues arising out of this situation with specific reference to the work of Knut Holter, as well as others. This situation and the challenges posed for a full and unencumbered encounter with the Hebrew scriptures and prospects for the future is explored.

Intradisciplinary and/or interdisciplinary implications: It is expected that the translation of the Hebrew scriptures involves interaction with local cultures and belief systems opening space for new interpretations from the perspectives of local world views and practices. The challenges for local Christian theologies and Christian doctrine in general arising from this are unavoidable.

\section{Introduction}

The Old Testament (OT) is much loved in Africa, perhaps due to its close cultural and religious affinities with traditional African culture and ethnic religions. When European missionaries first came to Africa in the 19th and 20th centuries they naturally gave preference to the New Testament (NT). The first translations of the Holy Scripture into the local languages in almost all cases started with the books of the NT, beginning with the Gospels and thereafter a few of the Epistles and then the entire NT. The OT usually followed some years later. For example, in the case of Kenya the first Lulogooli NT appeared in 1925 but the first OT appeared only in 1951; the first Dawida NT appeared in 1922 but the first OT appeared in 1998; the first Maasai NT appeared in 1923 but the first Maasai OT appeared in 1992; the first Luo NT appeared in 1926 but the first OT in 1957; the first Gikuyu NT appeared in 1926 but the first OT appeared in 1951. The major early exception to this trend was the Swahili Bible in Kenya and Tanzania where the first Zanzibar Swahili NT appeared in 1879 and the first OT in 1891, whilst the first Mombasa Swahili NT appeared in 1909 and the first OT in 1914. In Uganda the first Luganda NT appeared in 1893 and the first OT in 1896. For some languages, after the NT there was no follow-up work on the OT. Amongst these were the Pokomo where the 1902 NT had no followup, or the Kitaveta NT of 1906, amongst others (see e.g. Mojola 1999). It is interesting that some Bible agencies opted to produce and distribute only NTs. They could more accurately be described as NT agencies. There has, however, been much soul searching, and attitudes are changing fast. Some agencies that held fast to the idea of only the NT, have seen the wisdom of including at least some OT books, with Genesis, Exodus, Psalms, Proverbs, Ruth being amongst the most popular. It has become clear that the NT cannot be properly or fully understood outside of the contexts provided by the OT.

The spread of the church in Africa is inextricably connected to the translation of the Bible into the local tongues (see e.g. Sanneh 1989; Stine 1990; or Smalley 1991). As long as the Bible remained in the hands of the missionaries, it was possible for the missionaries to retain their control and authority in matters of faith and practice, at least in their sphere or domain of church influence. The translation of the Bible into the vernacular changed all that. It provided a basis for checking the sources and basis of the missionary message using the vernacular scriptures as a point of reference. The Bible in the vernacular offered local readers tools for interrogating 
and challenging this authority and control. Thus William Adrian (2007:289) is partly right in his suggestion that 'Bible translation has served to preserve and support indigenous cultures'. Moreover, Bible translation has also disrupted and been an agent within these same cultures, even causing the abandonment or transformation of certain traditions and values. David Barrett, in a pioneer and influential study of the African independent or initiated churches, demonstrated in his Schism and Renewal in Africa (1968) that the translation of the Bible into the vernacular languages provided the fuel and rationale for their proliferation. The Africa Instituted Churches (AICs) thus arose as an affirmation of the emerging indigenous readings and interpretations of the Bible and of the Christian faith and the appropriation and inculturation of these. Their emergence was also widely viewed as a reaction to the entrenchment of missionary readings and practices, as well as authority and control in the mission-dominated churches. The new readers empowered to read the Bible for themselves in their own languages felt equipped to challenge and question missionary readings and interpretations of the sacred text in their own languages. They too could hear God speaking in their own languages. As authorities and masters of their own tongues, they could justifiably argue that the missionary could in no way claim to understand their language better than they themselves. This development inevitably led to confrontations and disputations which eventually led to 'schisms and renewal', resulting in the then so-called African independent churches and now commonly referred to as the African initiated churches. Amongst the Protestant churches, some observers saw this as a continuation of the 'Protestant principle' that, in earlier times, had been appropriated by the new denominations and sects (following in the footsteps of Martin Luther, John Calvin, Thomas Cranmer and John Knox, amongst others). This was, however, not limited to the Protestant mission churches; it was evident within the Catholic churches as well. The processes of indigenisation, inculturation as well as independency have led to significant changes and transformation that these churches until recently assumed to be mission fields and are now quickly turning into missionary sending churches. The former missionary sending countries are increasingly becoming deChristianised and secularised, whilst Christianity is quickly becoming a non-Western religion.

\section{A non-Western Christianity and non-Western readings of the Bible}

The emergence of the AICs was clearly based on nonmissionary, non-Western readings of the Bible, amongst other factors. Stephen Neill (cited in Barrett 1968) was of the view that:

At the heart of this whole movement, directly or indirectly, will be found the sin of the white man against the black. It is because of the failure of the white man to make the Church a home for the black man that the latter has been fain to have a Church of his own. (p. 154)
David Barrett (1968) in his seminal text on this subject states that:

The root cause common to the entire movement of independency, therefore may be seen in this one aspect of culture clash: a failure of sensitivity, the failure of missions at one small point to demonstrate consistently the fullness of the biblical concept of love as sensitive understanding towards others as equals, the failure to study or understand African society, religion and psychology in any depth, rather than a dawning perception from the vernacular scriptures of the catastrophic nature of this failure and of the urgent necessity to remedy it in order that Christianity might survive on African soil. (p. 156)

Barrett (1968) elaborates that:

this failure of the version of Christianity proclaimed by the missions has been threefold, and can be elaborated briefly around three themes which we may term philadelphia, Africanism and biblicalism. Failure to practice the first led to inability to understand the second theme, which in turn led to a serious misunderstanding of the third. (p. 156)

It could be argued that the above factors, amongst others, necessarily influenced missionary readings, whether institutional or individual, and thus contributed to this tragedy.

Notwithstanding the above, it is widely acknowledged that all readings or interpretations generally presuppose the contexts as well as the prior experiences of their genesis. Such contexts and prior experiences provide the grid or prism (the eyes, so to speak) for seeing and the ears for hearing the given text in ways that do not contravene the constraints and limitations of the contexts. All readings are contextual. All readings are perspectival. Western readings and interpretations of the biblical text, like any other, both past and present, were necessarily constrained by the vicissitudes and realities of the Western reader or interpreter, just as African or Asian readings are constrained by African or Asian realities. The AICs were deeply influenced by readings steeped in African cultural and religious realities, and borne out of the vicissitudes of African historical realities, amongst them the reality of European colonial history and encounter.

Jehu Hanciles (2006) makes the observation that:

the transformation of Christianity into a non-Western religion has profound implications not only for the study of Christianity as a world religion but also, in more concrete terms, for the future of Christian missionary. (p. 60)

We might add for the purposes of this article that it has profound implications for the study of the OT and of the NT as well. Many of the missionaries who brought the good news of Jesus the Messiah to Africa in the 19th and 20th centuries tended to underrate the place of the OT in their work of mission in Africa. Some of them were afraid of highlighting the stories of the OT for fear that they would undermine or subvert their own missionary or westernising 
agenda because the OT seemed much closer to the African world, as for example in matters of the controversy surrounding the issue of polygyny, levirate marriage or remembrance of the living dead. Jonathan J. Bonk (2006) narrates the interesting case of David Picton Jones (cited in Krabill, Sawasky \& Van Engen 2006), a Welsh missionary of the London Missionary Society to East and Central Africa in the mid-19th century who:

in a letter to his home secretary ... had confessed that he could no longer believe in the divine inspiration of the Old Testament. The conjunction of his study of the Old Testament and his African experiences had unavoidably led him, he said, 'to the conclusion that the Hebraic moral and intellectual status was scarcely higher than that of the Africans. (Bonk 2006:83)

David Barrett (1968) and Allan H. Anderson (2001) offer well-researched overviews of the AICs, covering detailed surveys of West African, southern African, Central African and East African AICs as well as Pentecostal and Charismatic churches. The William Wade Harris or Harrist churches and the Aladura churches, both in West Africa; the Zionist and Apostolic churches, both in southern Africa; the Simon Kimbangu, Ngunzi and Alice Lenshina churches in Central Africa; the Akorino and Legio Maria; the East African Revival and other Spiritist churches in East Africa; or the new Pentecostal and Charismatic churches throughout Africa are only some of the well-known representatives of this reality. Common and unique to all these churches is the phenomenon of African spirituality and the complex dynamic interaction between Christianity and the diverse pre-Christian ethnic religions of the continent. These churches are deeply engaged with indigenous African religious and cultural realities, 'such as ancestors, divination, traditional medicine and healing, polygyny and traditional patterns of leadership ...' (Anderson 2001:194). Anderson (2001) points out for example that:

In many AICs in southern Africa, the prophet-healer has taken over the function of the traditional healer. In these churches the use of healing symbols is one of the central and most important features of church life and shows the 'direct-parallels' with traditional healing methods. (p. 199)

Inculturation and contextualisation with the attendant perils of syncretism are key issues in these churches. The Bible occupies a central place in the AICs, with the OT being given a special place of honour. Readers of these churches discern an abundance of similarities between African traditional religious practices and, especially, the OT. The Kenyan scholar, Jesse Mugambi (cited in Getui, Maluleke \& Ukpong 2001) is quite right in his view that:

When the Bible becomes accessible to African converts to Christianity, it becomes a companion text in their lives, because they can identify themselves and resonate with the biblical rhythm of life, especially in the Old Testament and in the synoptic gospels. Owing to the convergence between African and biblical ontologies, African interpretations of the Bible often become preoccupied with the search for resonance, rather than a quest for dissonance. (p. 16)

\section{Resonance or convergence between African and Old Testament worlds and stories}

As soon as the first texts of the OT appeared in African languages, the pioneer African readers of these texts could not avoid noticing the similarities between many of the stories of the OT and stories from their own cultures, between many OT religious practices and institutions and those of their own, in short the OT could easily have been read as an African book without much difficulty. There was indeed resonance and intuitive recognition of the familiar in the other. Notwithstanding the historical and temporal distance, the geographical and social distance, the religious and cultural distance between the peoples of the Bible and peoples of Africa, the gaps involved have been imaginatively bridged without difficulty. Geographically the societies and languages of the Ancient Near East are contiguous with those of Africa. The Semitic languages of the Middle East are part of a larger language family, the Afro-Asiatic language family which includes numerous languages found in North Africa, the Sahel region, the horn of Africa including Ethiopia, Djibouti, Somali, most of northern Kenya and parts of Tanzania. Readers of the Bible are moreover aware that North and North-Eastern Africa (and therefore Africa) are part and parcel of the story of the Bible, beginning with the Genesis stories. Mention of Egypt and Kush (or Ethiopia) abounds in the sacred text. Movement to and from Africa and contacts or networks between the two geographical centres are mentioned numerous times. The peoples and some of the key personalities in the biblical text are not strangers to the African world (see Holter 2000:93-106).

Knut Holter has been a leading contributor in the task of documenting African OT scholarship, often viewed as an invisible player in the world of biblical scholarship. In his Old Testament Research for Africa - A critical analysis and annotated bibliography of African Old Testament dissertations, 1967-2000 (2002), Holter provides information on 87 dissertations produced by black Africans between the 1960s and 1990s. In his Tropical Africa and the Old Testament - A select and annotated bibliography (1996), he looks at academic scholarly articles published mainly in journals from the 1930s to the 1990s. Holter $(1996,2000,2002,2006,2008)$ provides valuable data not easily accessible, collected over a period of several years. (Other key books by Knut Holter or edited together with colleagues on the same theme have resulted from conferences spearheaded by him in collaboration with African colleagues.) Both in the bibliographic collections and in the ensuing texts, key issues relating to institutional, thematic and contextual aspects of research and scholarship on the OT in Africa are extensively taken up. A critical review of the question of the institutional aspects related to the funding of African theological training and research on the OT is eye-opening. Church institutions in Anglophone, Francophone or even Lusophone Africa, not to forget the Coptic and Ethiopic Christian traditions, and their respective funding agencies have undoubtedly shaped the direction 
and shape of research and helped define ideological and doctrinal commitment and interests in their respective areas.

For Holter (2002), the list of dissertations so far published as exemplified in his bibliographic collection may be viewed as following in three phases as follows:

(a) the past (1960s-1970s) which created an institutional background for Old Testament scholarship in Africa

(b) the present (1980s-1990s), which experienced the breakthrough of an institutionalized scholarship in Africa

(c) the future (2000-), which will see the second generation of an institutionalized Old Testament scholarship. (p. 12)

The dissertations covered by Holter (2002) are products of certain theological institutions and often reflect certain of their research programmes, priorities and interests. Thus, for example, dissertations produced at Trinity International University, United States of America (USA); or at the Pontifical Urban University and at the Pontifical Lateran University, Rome, Italy; or at the Lutheran School of Theology, Chicago; or the Luther Seminary at St Paul, Minnesota, USA; or at the Dallas Theological Seminary, Dallas, USA, amongst others, will no doubt be characterised by certain institutional predilections including doctrinal and other theological interests. Institutional frameworks are important. Institutions determine criteria of membership and admission; they define boundaries and emphases. They possess a mission and vision which they aggressively pursue, and clearly the gatekeepers at these institutions determine which tunes will be played. When tunes are played in Rome or Dallas or Deerfield, Chicago, or Fuller or wherever, dancers from far-away Africa are not wanting. The implications of these institutional frames or contexts are far-reaching. Holter's three emphases contrast with the late Justin Ukpong's characterisation of African biblical scholarship since the 1930s to the present. Holter (2002) in reference to Justin Ukpong (1999) identifies three distinctive phases as characteristic of past and present African biblical research, namely:

(a) a reactive phase (1930s-1970s), which legitimized African religion and culture vis-à-vis the western tradition through comparative studies, (b) a reactive-proactive phase (1970s-1990s) which more clearly made use of the African context as a resource for biblical interpretation, and (c) a proactive phase (1990s), which made the African context the explicit subject of biblical interpretation. (Holter 2002:11)

Whilst the institutional implications of African biblical scholarship are important and far-reaching, the thematic undertones of this material, such as the keen interest in African traditional religious and cultural realities pointed to above, are equally surprising. This is conspicuously evident from a casual look at the evidence provided by Holter (2002).

Examples that seek to show similarities and convergences between the world of the OT and that of Africa abound. Attention is drawn here below to some of the pioneer articles in this regard. As early as 1904, M. Merker's
Die Masai - Ethnographische Monographie eines ostafrikanischen Semitenvolkes (Berlin 1904) presented according to Holter (1996):

a famous comparison of the Maasai with the OT Israel. A number of religio-cultural affinities are pointed out, and these are said to reflect the fact that the Maasai and the OT Israelites once constituted one single people. (p. 56)

Despite the exaggeration or falsehood that the Maasai and the OT Israelites constituted one single people or that they are both Semites, the main point is the similarities amongst them. These similarity claims are ubiquitous in Africa and cannot be dismissed or ignored. J. Torrend in his 1910 article, 'Likenesses of Moses' story in the Central Africa folk-lore' argued that 'some of the OT narratives about Moses have parallels in the Tonga tradition' (cited in Holter 1996:81). J.J. Williams in his book, Hebrewisms of West Africa: From Nile to Niger with the Jews ([1930] 1967 cited in Holter 1996:81), argued that 'similarities between life and thought of OT Israel and certain West African traditions ... are due to a historical contact between the two'. Again, if we ignore the speculation regarding the historical contact, it is clear that the point of departure for his speculations is the 'remarkable similarity' between the two! J-C. Bajeux in his 1956 article, 'Mentalite noire et mentalite biblique' (cited in Holter 1996):

compares African humanism and the Bible (especially the OT) and to Western culture, arguing that Africans are closer to the Bible than to the theology of Aquinas or the philosophy of Aristotle. (p. 28)

M. de Cocker in a 1950 article (cited in Knut Holter 1996:33), 'points out a great number of religio-cultural and socio-cultural affinities between the OT - especially from the Pentateuch and the historical books and certain traditional societies in Zaire.' M. J. Field (1958) in his article 'Ashanti and Hebrew shamanism' (cited in Holter 1996:40) 'points out some similarities between Ashanti shamanism and corresponding features described in the $\mathrm{OT}^{\prime}$.

The above were only precursors to what followed. Whilst Justin Ukpong (1999) takes the year 1930 as the beginning of the river, Holter (2000) prefers to place the start of this river in the 1960s arguing that:

the political and ecclesiastical independence of the 1960s, together with a rapid growth of theological seminaries and university departments of religion throughout the continent, and also a sudden wave of publications on Africa and the OT, makes it natural to start this survey with the 1960s. (p. 10)

This river has, however, distant sources and no doubt started much further back. If we were to extend the search to the experience and practices of the African Orthodox Christianities in North Africa, Nubia, Ethiopia and Eritrea, we would no doubt be taken back to the beginnings of the church in Africa during the Apostolic period and later, through to the 5th or 6th centuries when Ethiopian Orthodox Christianity was officially instituted and the Bible translated in Geez. 
The 1960s are however significant. They saw the publications of the older and pioneer African scholars, amongst them Kwesi Dickson of Ghana, John Mbiti of Kenya and Immanuel Idowu of Nigeria. These three have influenced an entire generation of African scholars and still continue to do so. Even though John Mbiti was a NT scholar, his writings have done much to open our eyes to the traditional African world. His PhD (Mbiti 1971) on NT eschatology in an African setting started a debate on African concepts of time and drew deeply on the inescapable reality of the African past, as well as culture and religion in the everyday lives of ordinary Africans. Currently, the vast majority of publications on biblical topics in Africa inevitably proceed from the viewpoint of the African religious and cultural contexts. ${ }^{1}$ The river has become a flood! The material in Holter's collection (see works cited 1996, 2000, 2001, 2002, 2006, 2008) may be taken to be only an indicator of the tip of the iceberg.

\section{The African Instituted Churches or African Independent Churches and the Old Testament}

Barrett, Ogot, Welbourn, Turner and others focused scholarly attention on the AICs in their pioneer studies on this emerging phenomenon. ${ }^{2}$ They contrasted these to the Western missionary churches. Whilst some Western missionary churches or some of their missionaries avoided, demonised and ostracised African religious and cultural realities thought to be dangerous and incompatible with the Christian faith, the AICs took the African realities as their point of departure or starting point. They engaged and interrogated the world of the Bible as understood in their readings of the Bible on the basis of their Africa-grounded mental grid and presuppositions. The beginnings of inculturation, indigenisation or contextualisation grew out of this encounter and were moulded in the crucible of the AICs.

It could be argued that the AICs operated and still operate on the principle of 'using Africa to interpret the Bible' (Getui, Holter \& Zinkuratire 2001:75). This means that they see the Bible from their own cultural perspective. This is unavoidable. It exposes one to the danger of susceptibility to read one's own cultural themes and meanings into the biblical texts. It makes it easy to identify elements of the Bible that are similar to one's own culture and context. Again herein lies the danger of reading these elements from the viewpoint of one's own culture and values. How to achieve a critical and balanced reading that respects both one's culture and the biblical text is obviously not easy. The preferred principle recommended by a majority of the missionary instituted churches has been that of 'using the Old Testament to interpret Africa' (Getui, Holter \& Zinkuratire 2001:131). This principle has operated

\footnotetext{
1.It is to be noted that only recently a new Chair of Mother Tongue Hermeneutics at the Trinity Theological Seminary, Legon, Ghana has been established to champion the principle of using Africa and African languages to interpret the Bible, and appropriately named in honour of two distinguished and highly respected Ghanaian appropriately named in honour of two distinguished and highly respected Ghanaian scholars - renowned theologian and Old Testament scholar, Kwesi Dickson, and
Gilbert Ansre, a renowned linguist of African languages, Bible translator and Bible Gilbert Ans
scholar.

2.See Barrett (1968), Welbourn and Ogot (1966), Turner (1967), Anderson (2001), amongst others.
}

on the assumption that the OT is God's Word, sharper than any two-edged sword, intended for bringing out the best in any culture or community. This might be understood to mean that the intention is to align the African world with that of the OT. Others understand this to mean that the OT does in this sense serve as a mirror for better understanding and evaluating one's own culture and context. Madipoane Masenya (ngwana 'Mphahlele) (2001) (cited in Getui, Holter \& Zinkuratire 2001), who seems to take this view, has it that:

the realism that traditional Africans experience as they interact with the OT ... [is] because it has the capacity to unlock African reality. If present day Africans still find it difficult to be at home with the OT, they might need to watch out to see if they have not lost their Africanness in one way or the other. (p. 145)

Others take the view that using Africa to read the Bible or the OT is bound to lead to syncretism, and all syncretisms are an evil. They would thus recommend using the Bible or the OT to interpret Africa. The OT or the Bible in this instance provides the mirror for seeing Africa, the criteria and yardstick for judging Africa. This is what is needed:

for teaching the truth, rebuking error, correcting faults, and giving instruction for right living, so that the man who serves God may be fully qualified and equipped to do every kind of good work. (1 Tm 3:16-17)

It is not, however, simply a case of ' $[u]$ sing Africa to interpret the Old Testament' (Getui, Holter \& Zinkuratire 2001:75) or ' $[u]$ sing the Old Testament to Interpret Africa' (Getui, Holter \& Zinkuratire 2001:131). It is really a case of both-and. The dialectical interaction between these two poles is what is needed to reach a fruitful synthesis. It is perhaps a case of seeing Africa in the OT and at the same time seeing the OT in Africa. This is what makes the OT an African book and Africa at home in the OT. AICs no doubt saw and see themselves in the OT and expect others to see the OT in their beliefs and practices. Whether this is so is a point of debate and contention.

\section{The future of the Old Testament in Africa}

The place of the OT in Africa is assured. The AICs have taken the lead to make the OT their book. The missionary instituted churches sometimes referred to as the 'Western instituted churches' (WICs) are slowly coming to accept the reality of the power of the OT in African contexts. They have realised that the NT without the OT is like a house without a foundation. The Summer Institute of Linguistics - an agency that has been involved in translating the NT into many of the world's languages in partnership with the Wycliffe Bible Translators - marginalised the OT for years by not supporting or participating in its translation. A shift in direction is now evident in these agencies. Exceptions are now being made to their 'NT only' translation policy. Clearly, many concepts, ideas, beliefs, practices as well as institutions portrayed in the NT are best grasped via the OT. It would therefore follow that attempting to introduce the NT in African contexts 
will lead the reader or interpreter to fall back on African contexts to help elucidate related or similar practices in the NT. Thus such concepts as circumcision, types of offerings, blood sacrifice, sin, polygamy, levirate marriage, kinship relations, et cetera are best understood on the basis of both the African contexts and the OT context. African readers naturally bring their cultural and religious background to their interpretive task.

Both the African background and the OT are sine qua non. However, the African Christian Bible interpreter needs the NT as well. The NT and the OT without the African background remain without an anchor. Both the NT and the OT require the African background for any contextualisation or inculturation to happen. Indigenisation and inculturation cannot happen without engagement with the social, cultural, religious and other local environments. The OT will no doubt be foundational to any continuing efforts at contextualising the Judeo-Christian scriptures.

It is widely acknowledged that the translation of the OT into the local languages widened the space for the new Christian readers to behold the full light. The NT by itself was inadequate. It did not fully connect to the social, cultural, religious and local environments and values. The missionary had the veto on all matters of faith - his interpretation of the Holy scriptures was authoritative and unquestionable. The OT brought a new awareness and understanding. It resonated with the local and empowered the new believers in their quest to better understand their new faith. Their search eventually led to rebellion and a departure from the received missionary tradition. It led to the formation of the AICs.

The work of translating the OT into the local African tongues is still ongoing and with it we can expect ongoing interpretations and appropriations of its message. According to the latest statistics released in May 2014 by the United Bible Societies in the Global Scripture Access Report, out of a total of over 7000 languages spoken worldwide, only 500 have a complete Bible, that is, both the OT and NT, and of which 1300 languages have the NT. Two thousand languages are spoken in Africa where the OT exists in only 196 African languages, whilst the NT exists in only 340 African languages. This means that of the 2000 and more African languages, only 196 of them have access to the OT in their own tongue!

How and by whom were these OT texts into African languages translated? The first translations of the OT into African languages were all translated by Western missionaries in collaboration or with the help of local speakers of these languages. Moreover, not all these translations were translated from the source Hebrew and Greek texts, that is, from the Biblia Hebraica and the Septuagint (also referred to as the LXX). Most of them relied on some of the older European language texts, that is, the older English, French or German translations. Some of the better ones depended on the missionaries' own European mother tongue translations such as the Authorized Version or the King James Version in English and equivalents in French or Portuguese. In some cases - where possible the translators consulted the Hebrew or Greek texts either directly or indirectly with help from experts. The majority of these first-generation translations tended to be literal or so-called formal correspondence translations.

The second generation translations of the Bible in African languages are being done by mother tongue speakers. The academic and theological training of these translators is varied. Some are struggling literates; others are moderately well trained academically and theologically; a few are very well trained both academically and theologically. The outcome is a mixture of translations of varying quality - from substandard to acceptable to very good. Yet this situation is a mirror of the institutional and contextual environment. Some churches and related church groups and related institutions prioritise and invest heavily in theological training whilst others look down on or discredit the same. For some languages finding qualified and capable translators is an uphill task, whilst for others qualified candidates abound. The discouraging and disappointing reality is that in many cases throughout the region trained theologians and biblical scholars evince little interest in their own vernacular scriptures. Critical studies, or commentaries, or reflections on vernacular scriptures is scanty. Surprisingly, much use is made of scriptures in the former missionary or colonial languages! This in all probability contributes to undermining any inculturation programme of the biblical texts in the local contexts.

In addition to encouraging the theological and biblical training of translators and other church workers, it is increasingly more important to especially encourage training in biblical languages. African biblical scholars who are competent and familiar with the source biblical texts are few and far between. The shortage of translators who have a competent command of these languages becomes more obvious and noticeable when the local Bible societies seek for candidates who satisfy this criterion for translation into the local languages. Theological and biblical training institutions in Africa will need to make it a requirement for all students to take biblical Hebrew and NT Greek courses as well as courses in the sociocultural and historical backgrounds of the biblical texts, as well as of the receptor languages and cultures. If these biblical languages were to be taught in an African language, or better still, in one's mother tongue, so much the better! It should also be pointed out that mother tongue speakers who are experts in African languages and linguistics, and especially in their own languages, as well as experts in cultural and literary studies, oral literature (orature), amongst other relevant studies, are few and far between.

\section{Conclusion}

Clearly the study of the OT in Africa is an exciting exercise with a bright future. It carries much promise for opening up fertile insights and fresh interpretations that are bound to revitalise the field both of OT scholarship and African 
Christianity. Knut Holter (2000) hit the nail on the head with this statement:

Just as the OT has proved to be an African book, to do OT scholarship has likewise proved to be an African enterprise. Therefore, wherever African OT scholarship will be heading, with regard to institutional context and thematic orientation, it deserves attention. (p. 25)

and, one might add, considerable financial and institutional support.

\section{Acknowledgements Competing interests}

The author declares that he has no financial or personal relationship(s) that may have inappropriately influenced him in writing this article.

\section{References}

Adrian, W., 2007, 'Is Bible translation "Imperialist"? Challenging another antiChristian bias in the academy', Christian Higher Education 6(4), 289-297. http:// dx.doi.org/10.1080/15363750500326631

Anderson, A.H., 2001, African Reformation - African Initiated Christianity in the 20th Century, Africa World Press, Trenton, NJ.

Barrett, D.B., 1968, Schism and renewal in Africa: An analysis of six thousand contemporary religious movements, Oxford University Press, Nairobi.

Bonk, J., 2006, “'And they marveled": Mammon as miracle in Western missionary encounter', in J. Krabill, W. Sawatsky \& C.E. van Engen (eds.), Evangelical, ecumenical and anabaptist missiologies in conversation: Essays in honor of Wilbert R. Shenk, pp. 78-87, Orbis Books, Maryknoll, NY.

De Cocker, M., 1950, 'Essai de parallelism Biblico-Congolais', Zaire 4, 277-298.

Field, M.J., 1958, 'Ashanti and Hebrew shamanism', Man 58, p. 14.

Getui, M., Maluleke, T. \& Ukpong, J. (eds.), 2001, Interpreting the New Testament in Africa, Acton Publishers, Nairobi/Peter Lang, New York.

Getui, M., Holter, K. \& Zinkuratire, V. (eds.) 2001, Interpreting the Old Testament in Africa, Acton Publishers, Nairobi.

Hanciles, J., 2006, 'God's mission through migration - African initiatives in globalizing mission', in J. Krabill, W. Sawatsky \& C.E. van Engen (eds.), Evangelical, ecumenical and anabaptist missiologies in conversation: Essays in honor of Wilbert $R$. Shenk, pp. 58-66, Orbis Books, Maryknoll, NY.
Holter, K., 1996, Tropical Africa and the Old Testament - A select and annotated bibliography, University of Oslo, Oslo. (Faculty of Theology Bibliography Series).

Holter, K., 2000, Yahweh in Africa - Essays on Africa and the Old Testament, Peter Lang, New York.

Holter, K., 2001, 'The Current State of Old Testament Scholarship in Africa: Where Are We at the Turn of fteh Century?', in M. Getui, K. Holter \& V. Zinkuratire (eds.), Interpreting the Old Testament in Africa, pp. 27-39, Acton Publishers, (eds.), Nairobi.

Holter, K., 2002, Old Testament Research for Africa - A critical analysis and annotated bibliography of African Old Testament dissertations, 1967-2000, Peter Lang, New York.

Holter, K., 2006, Let My People Stay! Researching the Old Testament in Africa, Acton Publishers, Nairobi.

Holter, K., 2008, Contexualized Old Testament scholarship in Africa, Acton Publishers, Nairobi.

Krabill, J., Sawasky, W. \& Van Engen, C.E. (eds.), 2006, Evangelical, ecumenical and anabaptist missiologies in conversation: Essays in honor of Wilbert R. Shenk, Orbis Books, Maryknoll, NY.

Madipoane Masenya (ngwana 'Mphahlele), 2001, 'Wisdom and Wisdom Converge: Selected Old Testament and Northern Sotho Proverbs', in M. Getui, K. Holter \& V. Zinkuratire (eds.), pp. 133-146, Acton Publishers, Nairobi.

Mbiti, J., 1971, New Testament Eschatology in an African Background: A Study of the Encounter between New Testament Theology and African Traditional Concepts, Oxford University Press, Oxford.

Merker, M., 1904, Die Masai: Ethnographische Monographie eines ostafrikanischen Semitenvolkes, Reimer, Berlin.

Mojola, A.O., 1999, God Speaks in our Own languages - Bible Translation in Kenya, Tanzania and Uganda from 1844 to 1998, the Bible Societies of Kenya, Tanzania and Uganda, Dodoma/Kampala/Nairobi.

Sanneh, L., 1989, Translating the Message - the Missionary Impact on Culture, Orbis Books, Maryknoll, NY.

Smalley, W.A., 1991, Translation as Mission- Bible translation in the Modern Missionary Movement, Mercer University Press, Macon, GA.

Stine, P. (ed.), 1990, Bible translation and the spread of the Church: The last 200 years, E.J. Brill, Leiden.

Torrend, J., 1910, 'Likenesses of Moses' story in the Central Africa folk-lore', Anthropos 5, 54-70.

Turner, H.W., 1967, 'A Typology for African Religious Movements', Journal of Religion in Africa 1, 18-21. http://dx.doi.org/10.1163/157006667X00011

Ukpong, J., 1999, 'Developments in biblical interpretation in modern Africa', Missionalia 27, 313-329.

United Bible Societies, 2014, 'Global Access Report', United Bible Societies, Swindon.

Welbourn, F.B. \& Ogot, B.A., 1966, A Place to Feel at Home, Oxford University Press, Nairobi.

Williams, J.J., [1930] 1967, Hebrewisms of West Africa, From Nile to Niger with the Jews, Biblo \& Tannen, London/New York. 